Studies in African Linguistics

Volume 22, Number 2, August 1991

\title{
ASPECTS OF BANDI TONOLOGY
}

\author{
Robert Mugele \\ Oracle Corporation \\ Irving, Texas
}

\author{
Michael Rodewald \\ The Institute for Liberian Languages
}

\begin{abstract}
Bandi tonology offers three points of interest. The first is low tone opacity. Several tone rules act to obscure the presence of underlying low tones in Bandi. In some cases low tones are lost completely while in other cases underlying low tones are manifested phonetically as downstep tones or as the low of a falling glide. The net result of Bandi tone rules is to create considerable opacity with respect to low tones. Second, is the treatment of polarizing tones. In Bandi, polarization rules cannot merely create a new tone, but must assign tone height to an underlying tone of unspecified tone height. Finally, there are formal problems that result from adherence to the OCP. A rule of tonal dissimilation becomes unduly complicated if it is assumed that the OCP prohibits sequences of like tones. A contrast between nouns with a LH and LLH melody also argues against the OCP.
\end{abstract}

\section{Introduction}

The Bandi ${ }^{1}$ language has a rich tonal system that provides numerous challenges for the analyst. Few studies of Bandi tonology exist, and they are limited in scope.

1The Bandi people live in northern Liberia. The traditional tribal area comprises a fifty mile arc stretching from the Guinea border in the north to the Lofa River in the south. This area today is included in the Kolahun administrative district of Lofa County, Liberia. There are an estimated 67,500 speakers of the Bandi language comprising six clans which, according to a survey conducted by The Institute for Liberian Languages [Sindlinger \& Thompson, 1975], are $96.5 \%$ cognate one with another. Linguistic innovations occur most often in the clans nearest the related languages of Loma to the east and Mende to the southwest. Welmers [1958] classifies these three languages along with Kpelle and Loko, as the Southwest Mande languages. The data for this paper were collected by Rodewald during six and a half years of work for The Institute for Liberian languages as a literacy and translation consultant among the Bandi people. All data 
2.1. H Tone Spread. The first phonetic rule involves the rightward spreading of a $\mathrm{H}$ onto a vowel which is already associated with a $\mathrm{L}$. The final morphemes in $(2 \mathrm{~b}, \mathrm{~d})(w a ̀$ ' $\mathrm{on}]$ and $l \grave{l}$ 'see') have falling tones, while in $(2 \mathrm{a}, \mathrm{c})$ these same morphemes have L's. In each case the preceding $\mathrm{H}$ has spread onto the final syllable resulting in a phonetic falling tone.
(2) a. pèlè wà
'on a path'
b. ndذ̀wòló wâ
'on land'
c. àà sùwà lò
'he can see an animal'
d. àà nìkà-ı́ kô
'he can see the cow'

H Tone Spread (HTS) operates throughout the speech string. Consequently phrase final L's are heard as falling tones. Phrase-internal L's that are affected by $\mathrm{H}$ Tone Spread are discussed in in the next section. The $\mathrm{H}$ Tone Spread rule is formulated as follows:

\section{H Tone Spread (HTS)}

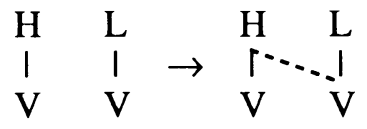

2.2. Contour Simplification. The next phonetic rule involves the delinking of a $\mathrm{L}$ from a phrase medial vowel upon which a $\mathrm{H}$ has spread (by HTS). The effect of delinking a $\mathrm{L}$ is to mask the presence of an underlying medial $\mathrm{L}$. Delinking does not occur when the vowel is followed by a phrase boundary as seen in the forms in (2) that ended with a falling tone. The various forms in (3) demonstrate the delinking of $L$.
(3) a. sánî
'bottle'
b. sání-ng!í
'the bottle'
c. sání mbà
'on a bottle'
d. àà nikà lò
'he can see a cow'
e. àà nìkà-í lô
'he can see the cow'
f. àà nikà-í ló!í vólú
'he can see the cow behind you' 
The underlying form of 'bottle' is /sáni/. The isolation form of 'bottle' is given in (3a) where $\mathrm{H}$ Tone Spread has applied giving the word final falling tone. ${ }^{3}$ The same stem, however, has a $\mathrm{H}$ on the second syllable when suffixed with the definite article, as in (3b), or when followed by a postposition as in (3c). Similarly, the verb $/ l \grave{l} /$ 'see' surfaces with three different tone melodies $(l \grave{l}, l \hat{b}$, and $l \hat{b})$. In (3d) it is preceded by a $L$ and the underlying $L$ of the verb is unchanged. In (3e) $H$ Tone Spread has spread the $\mathrm{H}$ of the preceeding definite marker $-i$ onto the verb producing a falling tone phrase finally. This same situation occurs in (3f), but the verb is no longer phrase final, consequently the $\mathrm{L}$ of the verb is delinked leaving only the $\mathrm{H}$ still linked. Thus a two syllable sequence within a phrase with an underlying $\mathrm{HL}$ tone sequence will surface as $\mathrm{HH}$. This is accomplished by first spreading the $\mathrm{H}$ ( $\mathrm{H}$ Tone Spread) to the second syllable and then by delinking the $\mathrm{L}$ when it is on a phrase medial syllable. It is clear that the $\mathrm{L}$ is merely delinked and not deleted because a following $\mathrm{H}$ is always downstepped as we see in (3b). We are calling this rule Contour Simplification:

\section{Contour Simplification (CS)}

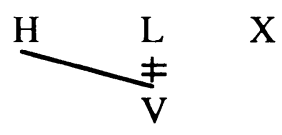

condition: $\mathrm{X}$ is not a phrase boundary

It is assumed that $\mathrm{H}$ Tone Spread has operated earlier to create the contour tone that is the input to Contour Simplification. Ordering also helps explain why there is no contour tone on mbà 'on' in (3c): H Tone Spread cannot reapply after Contour Simplification.

There is another possible analysis of this phenomenon. The above rules could be formulated as a single spreading and delinking rule as in (4).

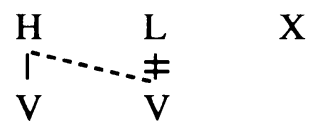

condition: $\mathrm{X}$ is not a phrase boundary

This alternative is shown to be incorrect in speech situations where this rule fails to apply and a phonetic contour is produced. Such situations occur when a speaker interrupts his/her speech and abnormally places a phrase boundary (or pause) following an underlying $\mathrm{H} \mathrm{L}$ sequence of tones. The presence of the

3 The underlying form of the word for 'bottle' never occurs on the surface. In isolation the final $\mathrm{L}$ tone is always masked by $\mathrm{H}$ Tone Spread resulting in a final falling contour. We posit this underlying form with confidence owing to the limited distribution of falling contours and the pervasive action of $\mathrm{H}$ Tone Spread throughout Bandi in producing all falling contours. 
contour tone in these situations is indicative of the prior application of $\mathrm{H}$ Tone Spread. Note the two derivations in (5) which show two different manifestations of the same underlying string when we assume an optional process we call Pause Insertion is part of the derivation ${ }^{4}$.

làà nìkà-í lò tì vòlúl

àà nìkà-í lô tì vòlú

\section{Pause Insertion \\ Contour Simplification \\ H Tone Spread} à nika-i lo ti volú àà nikà-í ló tì vòlú làà nikà-íl tò tì vòlúl

àà nikà-í lô tì vòlú

àà nikà-í lô \# tì vòlú

'he can see the cow behind them'

In the derivation on the left in (5) the phrase is acted upon normally by the two tone rules. The $\mathrm{H}$ of the definite marker - $i$ spreads to the verb $l \grave{b}$ 'see' by $\mathrm{H}$ Tone Spread and the resultant contour is simplified to a $\mathrm{H}$ by Contour Simplification. In the derivation on the right, the insertion of pause prevents the application of Contour Simplification and a phonetic falling tone remains on the verb. Thus, the rule proposed in (4) is shown to be incorrect. The above derivations also show that $\mathrm{H}$ Tone Spread must precede Contour Simplification.

2.3. Downstep. The last of the phonetic rules accounts for the downstepping of a $\mathrm{H}$ when preceded by a L. In Downstepping, the entire tone register is lowered. In other words, the pitch interval from $\mathrm{H}$ to $\mathrm{L}$ remains constant; however, following a $\mathrm{L}$, a $\mathrm{H}$ is phonetically slightly lowered in absolute pitch from a previous $\mathrm{H}$. Downstepping occurs whether or not the $\mathrm{L}$ is associated with a vowel. H's occurring after a downstepped $\mathrm{H}$ continue on the same relative pitch as the downstepped $\mathrm{H}$. The net effect of a Bandi speech string is that of a continual lowering or downdrifting in which each $H$ or string of $H$ 's preceded by a $L$ is phonetically lower than preceding H's. The downstepping rule is fomulated as follows:

\section{Downstep \\ $\mathrm{L} \mathrm{H} \rightarrow \mathrm{L} ! \mathrm{H}$}

The action of the three rules just described accounts for most $\mathrm{H}$ !H sequences where no $\mathrm{L}$ is apparent.

2.4. Noun Types in Isolation. The phonetic rules described above mask certain underlying tone melodies. We provide isolated tone patterns on nouns at this point

${ }^{4}$ Pause insertion can be compared to halting speech. 
because they can only be understood in light of the phonetic rules. For example, $\mathrm{H}$ Tone Spread will always cause an underlying HL melody on a noun in isolation to surface as H HL. The following chart shows the surface forms of nouns occurring in isolation following the application of the phonetic rules of $\mathrm{H}$ Tone Spread and Contour Simplification.

(6)

\begin{tabular}{|c|c|c|c|c|c|}
\hline & $\mathrm{CV}$ & CVV & CVCV & CVVCV & CVCVCV \\
\hline $\mathbf{L}$ & $\begin{array}{l}\text { mbà } \\
\text { 'rice' }\end{array}$ & $\begin{array}{l}\text { ndìi } \\
\text { 'heart' }\end{array}$ & $\begin{array}{l}\text { pèlè } \\
\text { 'road' }\end{array}$ & $\begin{array}{l}\text { kààlì } \\
\text { 'snake' }\end{array}$ & $\begin{array}{l}\text { mbòlòbà } \\
\text { 'cutlass' }\end{array}$ \\
\hline $\mathbf{H}$ & $\begin{array}{l}\text { kps } \\
\text { 'platform' }\end{array}$ & & $\begin{array}{l}\text { kéké } \\
\text { 'dog' }\end{array}$ & & \\
\hline LH & & $\begin{array}{l}\text { tèć } \\
\text { 'chicken' }\end{array}$ & $\begin{array}{l}\text { pèlé } \\
\text { 'house' }\end{array}$ & & \\
\hline LLH & & & $\begin{array}{l}\text { nyàhá } \\
\text { 'woman' }\end{array}$ & & $\begin{array}{l}\text { ndذ̀wòls' } \\
\text { 'earth' }\end{array}$ \\
\hline HL & & $\begin{array}{l}\text { káî } \\
\text { 'car' }\end{array}$ & $\begin{array}{l}\text { sánî̀ } \\
\text { 'bottle' }\end{array}$ & $\begin{array}{l}\text { péÉnì } \\
\text { 'pen' }\end{array}$ & \\
\hline LHL & & & $\begin{array}{l}\text { mìyâlmìyáâ } \\
\text { 'banana' }\end{array}$ & $\begin{array}{l}\text { glàásî̀ } \\
\text { 'glasss' }\end{array}$ & $\begin{array}{l}\text { siméndî̀ } \\
\text { 'cement' }\end{array}$ \\
\hline
\end{tabular}

Nouns with a L melody or LH melody are quite common in Bandi. While there are also a large number of nouns with a surface $\mathrm{H}$ melody, we maintain that the surface $\mathrm{H}$ pattern on the bulk of nouns is derived by rule while nouns with a lexical $\mathrm{H}$ melody are quite rare. (For example, only two CV nouns ( $k p s$ 'platform' and gbó type of animal) and two CVCV nouns (kéké 'dog' and tólś 'sunbird')with a lexical $\mathrm{H}$ melody have been recorded.) In addition, almost all nouns which exhibit a lexical HL or LHL pattern are clearly borrowed words. However, for a small number of these words, such as 'bottle' and 'banana', we do not have sufficient information to discern whether or not these nouns have been borrowed although we are strongly inclined to believe that they are. Also note that we have categorized the noun nyàha' 'woman' with LLH melody nouns even though it manifests a surface LH in isolation. There are numerous nouns which pattern like 'woman'. Reasons for categorizing these nouns as LLH will be discussed below.

2.5. Tone Mapping. In order to associate tone autosegments to the segmental tier we propose a tone mapping rule for Bandi. Tone mapping applies at the earliest stage of the derivation.

TONE MAPPING: Operating within morpheme boundaries and moving left to right, associate tones to vowels in a one to one manner. If there are more vowels than 
tones associate the rightmost tone to the remaining vowel(s). If there are more tones than vowels associate excess tones to the final vowel.

We are now ready to see the combined effects of tone mapping and the phonetic rules. The derivation in (7) demonstrates the actions of these rules.

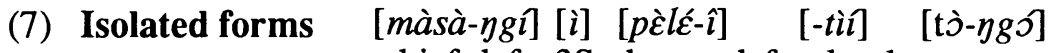

chief-def $3 S$ house-def plural see-pst

L H L LH L LH L H

UR masa-ngi i pele-i -ti i to-ngo

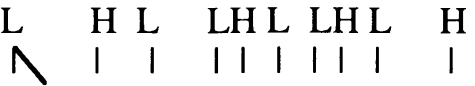

T-Mapping masa-ngi i pele-i -ti i to-ngo

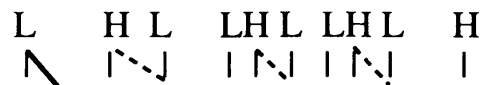

H Tone Spread masa-ngi i pele-i -ti i to-ngo

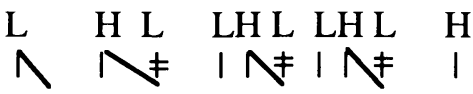

Contour Simp. masa-ngi i pele-i -ti i to-ngo

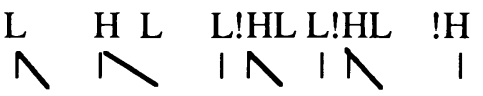

Downstep masa-ngi i pele-i -ti i to-ngo

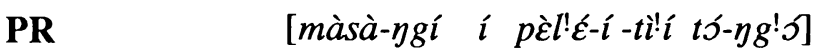

'the chief saw the houses'

As stated earlier, the domain of Tone Mapping (TM) in Bandi is the morpheme, therefore, in (7) TM is used to associate tone in a one-to-many manner only on the noun for 'chief'. Notice also that the underlying tone sequence for 'house' and 'see-pst' are both LH. However, in the surface form, the L of 'see' becomes a floating tone after being affected by $\mathrm{H}$ Tone Spread and Contour Simplification, whereas the initial L of 'house' is not affected by these rules and is manifested as a $\mathrm{L}$ tone in the surface form. As noted earlier the $\mathrm{H}$ following each of these L's becomes a downstepped $\mathrm{H}$ whether the preceding $\mathrm{L}$ is associated with a vowel or not. Thus, whenever a downstepped $\mathrm{H}$ is encountered in a surface form, a $\mathrm{L}$ can be posited immediately preceding the downstepped $\mathrm{H}$ in the tonal tier.

The overall effect of the rules of $\mathrm{H}$ Tone Spread and Contour Simplification is to mask the presence of some underlying L's. In many instances their existence 
can only be detected in two ways: by the presence of downstepped H's and as the last tone in phrase final falling contours.

\section{Morphological Tone Rules}

In addition to the phonetic rules, other tone rules may also operate within a phonological phrase. Since these rules always operate within a specific morphological context we call them morphological rules.

Besides the morphological tone rules, there is a segmental rule that changes the initial consonant of a stem from its underlying hard consonant alternation to its weak alternation. For example, the initial consonant $n d$ will become $l$ in the appropriate environment. Because this rule does not affect the tonal data we present we will not attempt to describe the appropriate environments or list the initial consonant alternations in this paper. In some derivations we will assume the previous operation of this segmental rule. In others, however, we will make provision for this rule to operate so that the reader may understand how the surface form is derived.

3.1. L Tone Displacement. Displacement of L's occurs when a $\mathrm{H}$ spreads onto a following vowel associated with a $\mathrm{L}$ and the $\mathrm{L}$ is deleted from the tonal tier. We call this rule L Tone Displacement.

Although similar in some respects, L Tone Displacement differs from the phonetic rule of $\mathrm{H}$ Tone Spread. In $\mathrm{H}$ Tone Spread, $\mathrm{H}$ spreads rightward onto a vowel associated with a $L$. Even in those situations where the $L$ is delinked (as occurs phrase internally) the $\mathrm{L}$ remains on the tonal tier, but unassociated with any vowel and is manifested phonetically as either a downstep or fall. By contrast, in L Tone Displacement, there is no $\mathrm{L}$ influence such as a downstep or fall remaining in the surface form. We represent this difference by spreading a $\mathrm{H}$ onto a vowel associated with $\mathrm{L}$, but with the effect that the $\mathrm{L}$ is completely deleted, not merely delinked. The difference between H Tone Spread and L Tone Displacement is demonstrated in (8). In (8a), the H of $m b a ̀-i$ 'rice-def' spreads onto the following postposition resulting in a fall. In example (8b), the $\mathrm{H}$ of $p \grave{\varepsilon} l \hat{\varepsilon}$ 'house' spreads onto the following postposition and completely replaces the $\mathrm{L}$ with no phonetic manifestation of the original $\mathrm{L}$.
(8)
a. H Tone Spread
$m b \grave{a}-\grave{\imath}+w \grave{a} \rightarrow m b a ̀-i ́ w a ̂$
'on the rice'
b. L Tone Displacement
$p \grave{\varepsilon} l \hat{\varepsilon}+w a ̀ a \rightarrow p \grave{\varepsilon} l \hat{\varepsilon} w a ́$
'on a house'

L Tone Displacement is a morphologically conditioned rule; only verbs, modifiers, postpositions, and nouns may undergo this rule. Initial L's on these morphemes are displaced and deleted by the spread of a preceding $\mathrm{H}$ in three situations: first, when a noun or pronoun with a $\mathrm{H}$ or $\mathrm{LH}$ melody precedes a verb 
in a verb phrase as in (9a); second, when either a noun or pronoun with a $\mathrm{H}$ or $\mathrm{LH}$ melody precedes a noun or modifier in a compound as in (9b); or third, when either a noun or pronoun with a $\mathrm{H}$ or $\mathrm{LH}$ melody precedes a postposition in a postpositional phrase as in (9c-e). If any of these morpheme orders occur, the final $\mathrm{H}$ of the first morpheme spreads to the following syllable displacing and deleting a resident $\mathrm{L}$. The examples in (9c-e) also show that the tone on the noun/pronoun may be either a $(\mathrm{H}) \mathrm{H}$ or $\mathrm{LH}$.
a. kéké + lùkpé
$\rightarrow \quad$ kéké lúkpé
'push a dog'
b. kéké +wù-ngi $\rightarrow$ kékéwú-ngí
'the dog head'
c. kéké + wà
$\rightarrow \quad$ kéké wá
d. $p \grave{\varepsilon} l \underline{\varepsilon}+w a ̀$
$\rightarrow$ pèlé wá
e. $i+w \grave{a}$
$\rightarrow \quad$ i wá
'on a dog'
'on a house'
'on you'

There are no downstepped H's in $(9 a, b)$ as would be expected had H Tone Spread, Contour Simplification, and Downstep operated on these forms.

If a noun or pronoun has an underlying tone melody other than $\mathrm{H}$ or $\mathrm{LH}, \mathrm{L}$ Tone Displacement does not operate. When nouns or pronouns with L, HL, or LLH $^{5}$ melodies precede a morpheme with an initial $\mathrm{L}$, that initial $\mathrm{L}$ will remain unchanged by $\mathrm{L}$ Tone Displacement. It is, however, subject to subsequent rules such as H Tone Spread.

The examples in (10) all fail to undergo L Tone Displacement. Examples (10a-d) all fail because the tone patterns on the first morpheme of the phrase is not $\mathrm{H}$ or LH. The examples in (10e-i) fail because the appropriate morphemes are not adjacent to each other. In (10a, d, e, f) the failure of $\mathrm{L}$ Tone Displacement to apply allows the operation of the phonetic tone rules, causing a downstep to appear in (10a, e, g) and a final fall to appear in (10d, h).
a. ndذ̀w ̀̀ló + lùkpé
$\rightarrow$ ndذ̀wذ̀ló lúkp!é
'push earth'
b. $t \grave{\imath}+w \grave{a}$
$\rightarrow$ tì wà
'on them'
c. nìkà +wà
$\rightarrow$ nìkà wà
'on a cow'
d. ndذ̀wذ̀ló + wà
$\rightarrow$ ndذ̀wذ̀ló wâ
'on land'
e. màsà-ngí + lùkpé
$\rightarrow$ màsà-ngí lúkp!é
'push the chief'

\footnotetext{
${ }^{5}$ Note that an LLH melody violates the OCP. There are nouns in Bandi that pattern as if they have an underlying LH melody and others that pattern as if they have an underlying LLH melody. Mende nouns have a similar distinction [Leben 1978]. Leben dealt with this by maintaining the OCP and developing a complex set of tone mapping rules. Later in this paper we present data to show that adherence to the OCP also complicates Bandi verb morphology.
} 

f. màsà-ngâî + tùkpé $\rightarrow$ màsà-ngái tùkpé6
'push the chiefs'
g. tè-í + lùkpé $\rightarrow$ tè-íl lúkp!é
'push the chicken'
h. ngù-ngí +wà $\rightarrow$ ngù-ngí wâ
'on the/his head'
i. kéké-î + lùkpé
$\rightarrow$ kéké-í lùkpé
'push the dog'

As an historical note it is highly likely that the condition on $\mathrm{L}$ Tone Displacement is derived from nouns whose historical melody is $\mathrm{H}$. Cognates of many Bandi LH melody nouns, such as pè lé, exhibit $\mathrm{H}$ melodies in other Southwest Mande languages. Dwyer [1973, 1974] posits an historical "prereference" marker which he suggests causes the strengthening of noun initial consonants in Southwest Mande languages. It is interesting to speculate that the segmental material of this particle prefix $\left({ }^{*} \grave{n}\right)$ decayed leaving a floating $\mathrm{L}$. This tone eventually became a part of synchronic tone melodies by spreading onto the first syllable of synchronic nouns, in effect pushing the original melody one syllable to the right. Thus, historical $\mathrm{H}$ melodies on nouns have become synchronically LH and historical LH melodies have become LLH. If this is the case, then it appears that a fairly simple historical condition has become synchronically complex and serves to explain why it is that only $\mathrm{H}$ and $\mathrm{LH}$ melodies spread and delete a following tone whereas LLH melodies do not. If we adopt this interpretation we could simplify the condition of $\mathrm{L}$ Tone Displacement by saying that the $\mathrm{H}$ is part of an historical $\mathrm{H}$ melody.

The L Tone Displacement rule may be formulated as follows.

\section{Tone Displacement (LTD)}

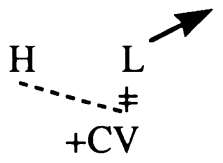

$$
\begin{array}{ll}
\text { Where }(+)=\text { boundary between either } & 1 . \text { noun/pronoun }+ \text { postposition } \\
& \text { 2. noun/pronoun }+ \text { modifier/noun } \\
& \text { 3. object noun/pronoun }+ \text { verb }
\end{array}
$$

An arrow has been used in order to denote the delinking and complete deletion of the $\mathrm{L}$. The deleted $\mathrm{L}$ has no influence, such as downstep, on subsequent rules.

The following derivations contrast morphemes with a $\mathrm{H}$ or LH melody (11a and 11c), which cause L Tone Displacement to occur, with other word melodies (11b and 11d), which do not cause L Tone Displacement to occur.

${ }^{6}$ Note that the initial consonant of the verb tùkpé/lùkpé 'to push' alternates. This initial consonant alternation is common in Bandi and occurs in a morphological environment identical to that we have outlined for $\mathrm{L}$ Tone Displacement. 
(11) Isolated

forms

UR

Seg. rules

L Displ. a. pèlétmbà house+on

L H L

pele mba

L H L

pele wa

$\begin{array}{cc}\text { L H } & \text { L } \\ \text { | I } & \text { । }\end{array}$

Tone Map. pele wa

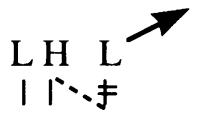

pele wa b. ndذ̀wذ̀lótmbà land+on

L L H L

ndowslo mba

L L H L

ndowslo wa

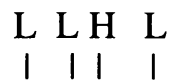

ndowolo wa

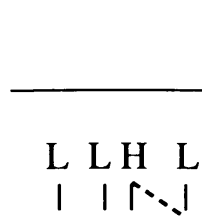

ndowolo wa
PR

H Tone Spr.

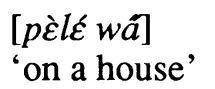

[ndذ̀wذ̀ls wâ] 'on land'

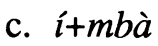

$2 \mathrm{~S}+$ on

d. $t \grave{l}+m b \grave{a}$

3PL+on

$\mathrm{H} \quad \mathrm{L}$

i mba

H L

L L

i wa

$\begin{array}{cc}\mathrm{H} & \mathrm{L} \\ \text { I } & \text { I }\end{array}$

i wa

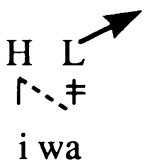

[íwá]

'on you' ti wa

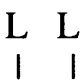

ti wa

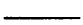

It is not necessary for a $\mathrm{H}$ to be associated to the segmental tier in order for $\mathrm{L}$ Tone Displacement to occur. Assume for the moment that the underlying melody for tùkpé 'to push' is LH. Since our tone mapping rule for Bandi is limited to morpheme by morpheme mapping, conditions will arise where morphemic tones are not associated by the tone mapping rule. For example, in Bandi the ' $1 \mathrm{~S}$ ' pronoun morpheme is a floating $\mathrm{H}$. When this ' $1 \mathrm{~S}$ ' $\mathrm{H}$ pronoun occurs before a verb, postposition, or noun, Tone Mapping does not associate this tone to a vowel. Floating tones left in this manner become associated through $\mathrm{L}$ Tone Displacement. This process is demonstrated in (12).

$$
\begin{aligned}
& \mathrm{H}+\mathrm{L} \quad \mathrm{H} \quad \mathrm{TM} \quad \mathrm{H}+\underset{\mathrm{I}}{\mathrm{L}} \underset{\mathrm{I}}{\mathrm{H}} \\
& + \text { tukpe } \rightarrow \quad+\text { tukpe } \\
& \rightarrow \quad+\text { tukpe 'push me' }
\end{aligned}
$$

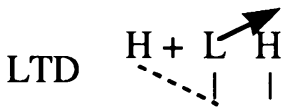

3.1.1. Objections to $\mathrm{L}$ Tone Displacement. There is a possible alternative analysis to the data we have provided in support of $\mathrm{L}$ Tone Displacemement. In Dwyer's [1973:118] treatment of Bandi nouns he proposes a rule of Low Tone Advancement. Many of the forms that we treat as saving an underlying LH 
melody, Dwyer would treat as having a simple $\mathrm{H}$ melody. Low Tone Advancement then spreads a $\mathrm{L}$ from a preceding morpheme to the right. This results in a surface LH melody. If we were to extend Dwyer's analysis to verbs, we might posit that the underlying form of the verb 'to push' (presented as LH, lùkpé, in (9), (10), and (12)) has an underlying H melody, lúkpé. Notice in (13) that the verb 'to push' alternates between a LH pattern and a HH pattern. Dwyer's analysis would predict that all of the LH patterns are the result of spread from the preceding L. Following this reasoning we must assume a floating $\mathrm{L}$ preceding the verb in (13c).
a. túkpé
'push me'
b. í lúkpé
'push you'
c. tùkpé
'push (something)'
d. mù lùkpé
'push us (inclusive)'
e. nì lùkpé
'push us (exclusive)'
f. wú lúkpé
'push you (plural)'
g. tì lùkpé
'push them'

We reject this analysis. The forms in (14) demonstrate the presence of an underlying $\mathrm{L}$ on the verb stem. Note in $(14 \mathrm{a}, \mathrm{b})$ that $\mathrm{L}$ appears on the verb even though no apparent $\mathrm{L}$ occurs on the preceding morpheme to trigger a rule such as Low Tone Advancement. In addition, in (14c-f) the verb appears with a surface $\mathrm{H}$ !H pattern. We claim this pattern is the result of the phonetic rules of $\mathrm{H}$ Tone Spread and Contour Simplification. If the underlying melody of the verb is considered to be $\mathrm{H}$, there is no explanation for the downstepped $\mathrm{H}$.
a. sáni tùkp!é
'push a bottle'
b. pèlé-i lùkpé
'push the house'
c. sání-ng!í lúkp!é
'push the bottle'
d. sùwà-í lúkp!é
'push the animal'
e. sùwà-í-tî́i túkp!é
'push the animals'
f. sáni-ng!á-i-ti! túkp!é
'push the bottle'

Another common analysis in Southwestern Mande languages [Leben 1978] has been to posit toneless morphemes, more specifically toneless postpositions. These toneless postpositions receive tone according to tone mapping rules which spread the final tone of the preceding morpheme onto the postposition. However in Bandi, this type of analysis also fails. Consider the surface forms in (15). 


\begin{tabular}{|c|c|c|c|}
\hline 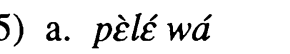 & 'on a house' & pèlé yélé & 'to a house' \\
\hline b. pèlé-i wà & 'on the house' & pèlé-í yèlé & 'to the house' \\
\hline c. pèlè wà & ‘on a road' & pèlè yèlé & 'to a road' \\
\hline d. pèlè-í wâ & 'on the road' & pèlè-í yél!é & 'to the road' \\
\hline 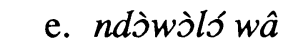 & 'on earth' & ndòwòlb yél!éé & to earth' \\
\hline
\end{tabular}

At first glance the data in $(15 \mathrm{a}, \mathrm{c})$ might appear to support tonelessness on at least the first syllable of Bandi postpositions. The tone of the first syllable of the postpositions 'on' and 'to' is identical to that of the final syllable of the preceding noun. However, in (15b) we see the initial tone of the postposition is the opposite of the preceding definite morpheme. In addition, the single syllable postposition 'on' in $(15 \mathrm{~d}, \mathrm{e})$ is preceded by a morpheme with a final $\mathrm{H}$ but exhibits a falling tone while in that same environment the two syllable postposition 'to' exhibits a $\mathrm{H}$ !H pattern. If we adopt Leben's "toneless postposition" analysis for Bandi we must posit ad hoc floating tones in abundance in order to explain the above data. Therefore we reject an analysis that posits toneless postpositions in Bandi. The advantage of our analysis is that $\mathrm{L}$ Tone Displacement helps us to account for tone morphophonemics on verbs, postpositions, and compounds. Thus, it is not necessary to posit abstract tone melodies and/or toneless morphemes.

3.2. Polarization. Some Bandi morphemes which never occur in isolation have underlying polarized tone. A polarized tone is a tone which is opposite in height of a neighboring tone [Hyman \& Schuh 1974]. A polarizing tone may polarize with respect to either a following or a preceding tone in a specific language. In Bandi, there are two rules of polarization, one where a tone polarizes with respect to a preceding tone, and another that polarizes with respect to a following tone. We call these rightward polarization and leftward polarization respectively. All instances of polarizing tones in Bandi are associated with particular morphemes, such as one of the two definite markers for nouns, certain subject pronouns, and one verb suffix. This is consistent with the observations of Hyman \& Schuh [1974] and Schuh [1978] that polarization is generally limited to particular morphemes in a language.

A possible approach to formalizing polarizing tones is to lexically mark a polarizing morpheme with the feature [+pol] which would trigger a rule of the following form:

$\left.\begin{array}{l}\text { (16) } \\ {[+ \text { pol }]}\end{array}\right][\alpha \mathrm{H}] / \longrightarrow[-\alpha \mathrm{H}]$

Such a notation raises some difficulties. First, by treating a polarizing morpheme as essentially toneless (but with the diacritic $[+$ pol]) problems are created when 
Tone Mapping operates. Tone bearing units associated with [+pol] would be toneless on the tonal tier, and one would expect that they would receive a tone through Tone Mapping. For example in Bandi the 3rd. pl. potentive pronoun has the following form:

(17) tàa before an underlying $\mathrm{H}$

tàá before an underlying $\mathrm{L}$

If we choose to represent the morpheme in (17) as simply having a $\mathrm{L}$ and the [+pol] diacritic, Tone Mapping (unless modified) would spread the $\mathrm{L}$ to both vowels. This would then complicate the polarization rule by forcing it to delete (or delink) a tone before creating the polarized output. For example if the form in (18), where the second vowel has a polarized tone, were followed by an underlying $\mathrm{L}$, polarization would have to first delink the tone from the second vowel and then associate a $\mathrm{H}$ to it.

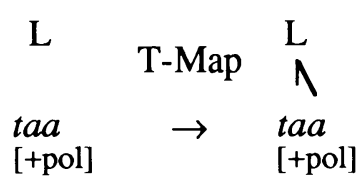

Another reason for treating Bandi polarizing tones as separate tones on the tonal tier is that they act as a third tone in what is essentially a two tone ( $\mathrm{H}$ and $\mathrm{L}$ ) system. Tones which derive from underlying polarized tones are immune to certain rules. For example, L Tone Displacement, which affects underlying L's, does not affect L's created through polarization. Likewise, H's derived from underlying polarized tones can never be the $\mathrm{H}$ that displaces a $\mathrm{L}$ as in $\mathrm{L}$ Tone Displacement.

For these reasons, Polarizing tones are ascribed status as an independent underlying tone rather than treating them as a [+pol] diacritic feature on a tone bearing unit. We represent these tones underlyingly with a $\mathrm{P}$ in the tonal tier to indicate the presence of a tone of unspecified height. In this way we distinguish them from underlying H's and L's and at the same time allow them to associate with vowels via Tone Mapping. By using the P notation on the tonal tier some advantages become apparent. First, polarized tones can be associated normally via Tone Mapping without modification (as noted previously). Second, since polarizing tones are treated as tones, it is natural that they operate as tones on the tonal tier rather than receiving tone height in accordance with a feature on the segmental tier. Third, the presence of $\mathrm{P}$ on the tonal tier, will block the operation of L Tone Displacement, which affects a following associated L. For example, $\mathrm{L}$ Tone Displacement can create the incorrect tones in (14a) when the diacritic [+pol] 
is used. However, the presence of the P tone on (19b) blocks the inappropriate application of L Tone Displacement (LTD).
a. $\underset{\mathrm{L}}{\mathrm{I}} \mathrm{H}$
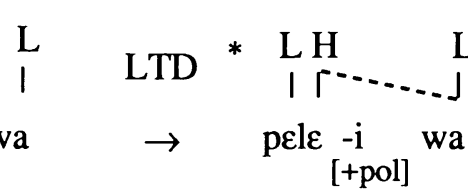

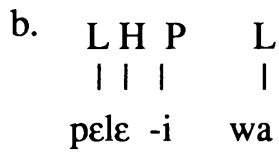

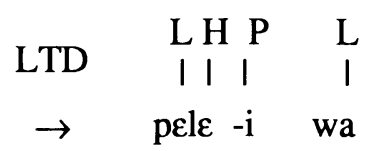

Without the P notation on the tonal tier, rule formulation would need to be complicated in order to be sensitive to the segmental feature [+pol]. With the use of $\mathrm{P}$, the action of tone rules is kept in the tonal tier rather than reaching into the segmental tier.

$\mathrm{H}$ and $\mathrm{L}$ tones created through the process of polarization do undergo the normal effects of the phonetic rules discussed above. Thus, polarization rules must be ordered before the phonetic tone rules of $\mathrm{H}$ Tone Spread, Contour Simplification, and Downstep.

3.2.1. Right Polarization. Only one morpheme in Bandi polarizes with respect to the preceding tone. This morpheme is the definite marker /-i/ which may occur in the noun phrase. For example, /pèlèti/ 'road + def' becomes [pèlè-í] whereas

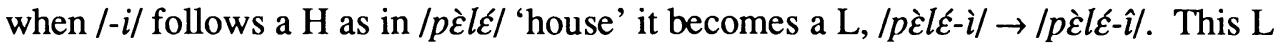
is then also subject to a phonetic spread from the preceding $\mathrm{H}$ and depending upon its position in the phonological phrase, it may be delinked via the Contour Simplification Rule.

The following rule and derivations illustrate polarization relative to the preceding tone. This process has been labeled Right Polarization. The presence of the feature [+def] in the rule indicates that only a morpheme lexically marked with [+def] will undergo Right Polarization. All other Polarizing tones will undergo Left Polarization (see below).

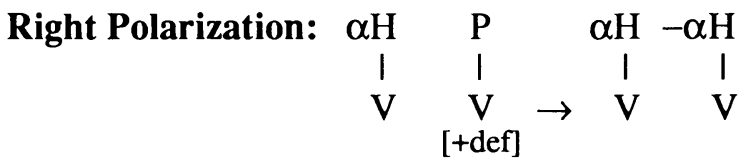


(20) Isolated Forms [pغ̀lé-î] 'house-def' [pèlè-í] 'road-def' [mbà] 'on'
L H P L
L $\quad P \quad L$

UR

$$
\begin{array}{ll}
\text { pele -i mba } & \text { pele -i } \\
\text { house-def. on } & \text { road -def on }
\end{array}
$$

L H P L

L $\quad P \quad L$

Seg Rules

pele -i wa

pele $-\mathrm{i} \quad$ wa

T-Map

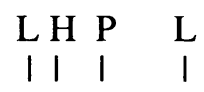

L Tone Displ.

pele -i wa

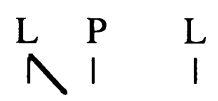

pele $-\mathrm{i} \quad$ wa

\section{H L L \\ I l l I}

R-Polarization pele -i wa

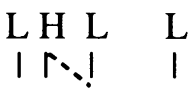

H Tone Spread pele -i wa

$$
\begin{aligned}
& \text { L H L L } \\
& \text { I } P . \neq
\end{aligned}
$$

Contour Simp pele -i wa

PR [pèlé-í wà $]$
'on the house'

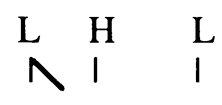

pele $-\mathrm{i}$ wa

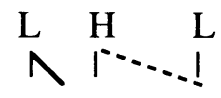

pele $-\mathrm{i} \quad$ wa

3.2.2. Left Polarization. Polarization of tone also occurs to the left on some Bandi morphemes. That is, some vowels receive a tone opposite in height to the associated tone which follows them. Leftward polarization is also governed morphologically. For example, subject phrases in Bandi require a recapitulative pronoun which contains tense and aspect. We call this pronoun a tense/aspect pronoun. Leftward polarization occurs on the final vowel of tense/aspect pronouns which correspond to 1 st person plural inclusive, 1 st person plural exclusive, and $3 \mathrm{~d}$ 
person plural. Leftward polarization also occurs on the final vowel of the stative

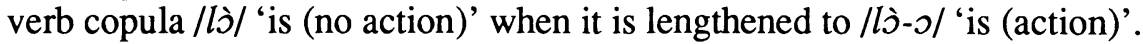

Through the action of the phonetic rules, H's created through leftward polarization spread phonetically onto the following vowel and may delink a $\mathrm{L}$ associated with that vowel. Thus, the phonetic rules may mask an underlying $\mathrm{L}$ which governs the creation of a $\mathrm{H}$. For example, in (21a) below, the underlying P-L sequence associated with the 3PL pronoun and the first syllable of 'house', becomes HL via the leftward polarization rule. The HL sequence then undergoes the phonetic rules of $\mathrm{H}$ Tone Spread and Contour Simplification leaving a final phonetic sequence of $\mathrm{HH}$. The underlying $\mathrm{L}$ from which the polarized tone received its tone is only apparent in the surface form by the downstepping on the $\mathrm{H}$ which follows it.

The following rule and derivations illustrate leftward polarization using the $3 \mathrm{~d}$ person plural tense/aspect pronoun $/ t i /$.

$\begin{array}{lllllll}\text { Left Polarization: } & \mathrm{P} & \alpha \mathrm{H} & & -\alpha \mathrm{H} & \alpha \mathrm{H} \\ & \mathrm{I} & \mathrm{I} & & \mathrm{I} & \mathrm{I} \\ & \mathrm{V} & \mathrm{V} & \rightarrow & \mathrm{V} & \mathrm{V}\end{array}$

(21) Isolated Forms [pغ̀lर́-îl] house-def

[kéké-î] dog-def

$$
\text { P L H P L H }
$$

UR

T-Map

Seg Rules

T-Man

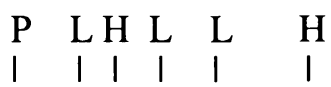

R-Polarization ti pele -i lo -ngo

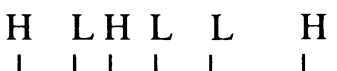

L-Polarization

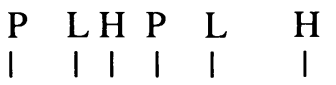

ti pele -i lo - -ngo

ti pele -i to -ngo

they house-def saw-pst

P L H P L H

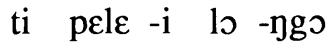

ti keke-i lo -ngo

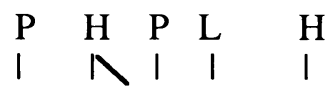

ti keke-i lo -ngo

ti keke-i to -ngo they dog -def saw-pst

$\begin{array}{lllll}\mathrm{P} & \mathrm{H} & \mathrm{P} & \mathrm{L} & \mathrm{H}\end{array}$

$\begin{array}{lllll}\text { P } & \mathrm{H} & \mathrm{L} & \mathrm{L} & \mathrm{H} \\ \mathrm{I} & \mathrm{N} & \mathrm{I} & \mathrm{I} & \mathrm{I}\end{array}$

ti keke-i lo -ngo

$\begin{array}{lllll}\text { P } & \text { H } & \text { P } & \text { L } & \text { H }\end{array}$ 


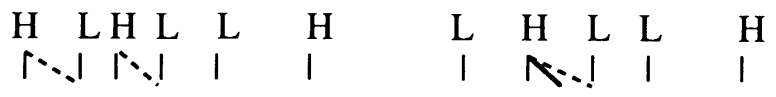

H Tone Spread ti pele -i lo -ngo ti keke-i lo -ngo

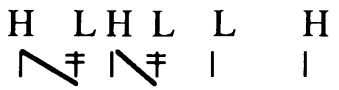

Contour Simp. ti pele -i lo -ngo

Downstep

PR

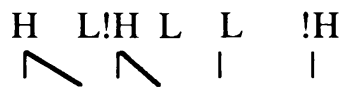

ti pele -i lo - ngo

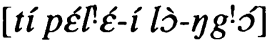

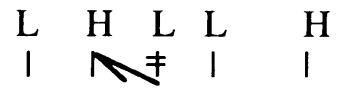

ti keke-i lo -ngo
$\begin{array}{lllll}\mathrm{L} & \mathrm{H} & \mathrm{L} & \mathrm{L} & \text { !H } \\ \mathrm{I} & \mathbf{N} & \mathrm{I} & \mathrm{I}\end{array}$

ti keke-i lo -ngo [tì kéké-í lò-ng!ó]

'they saw the dog'

Polarization rules occur before the phonetic rules but are ordered after other rules, such as L Tone Displacement, have applied. Thus, a polarizing tone will derive its height, i.e. $\mathrm{H}$ or $\mathrm{L}$, from a $\mathrm{H}$ that spreads due to $\mathrm{L}$ Tone Displacement. This is evidenced in the following two derivations. The first, (22a), orders Right Polarization before L Tone Displacement, but produces incorrect output. The second derivation, $(22 \mathrm{~b})$, reverses the order of these two rules and correctly produces [ $[\mathbf{i} w o ́-\hat{\imath}]$ 'your stomach-def'.

(22) $[k \grave{o}-i ́]$ 'stomach'

$$
\text { HLP }
$$

a. $i k o-i \stackrel{\text { reg }}{\text { rules }} \rightarrow \quad i w o-i$

'they saw the house' [í wó-îl] 'your stomach'

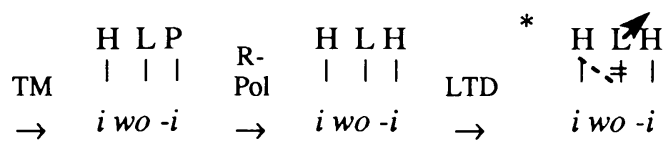

H L P

b. $\quad i k o-i \stackrel{\operatorname{seg}}{\text { rules }} \rightarrow$ iwo $-i$

H L P

TM $\quad \begin{array}{llll}\mathrm{H} & \mathrm{L} & \mathrm{P} \\ \mathrm{I} & \mathrm{I}\end{array}$

$\begin{array}{ccccc} & \text { H LP } & & \text { H } & \text { L } \\ \rightarrow \cdot \neq 1 & \text { Pol } & \text { । } \\ \rightarrow \quad i w o-i & \rightarrow & i w o-i\end{array}$

$\underset{\text { HTS }}{\rightarrow} \quad \stackrel{\mathrm{L}}{\mathrm{H}} \mathrm{i}-\mathrm{l}$

3.2.3. A Mid Tone Analysis? It is tempting to analyze polarizing tones as historical mid tones which maximally differentiate themselves from a neighboring tone through polarization. However, there is no evidence for a synchronic mid tone in Bandi. We merely speculate here that polarizing tones such as those in Bandi may have a historical source as mid tones in a three level tone system that later collapsed into a two level system. 
3.3. Dissimilation. Dissimilation rules differ from polarization rules. We saw earlier that polarization operates on a tone that has no inherent pitch height and assigns either a $\mathrm{H}$ or $\mathrm{L}$ that is the opposite of the height of a neighboring tone. Dissimilation is similar in its effects, but in dissmilation there is always an identifiable underlying tone [Hyman \& Schuh 1974:100].7 In Bandi, tonal dissimilation occurs when a $\mathrm{L}$ \# L sequence becomes H \# L. Note that in (23) that the final L's of the verbs $b \varepsilon$ and víli become $\mathrm{H}$ preceding the postposition.
Diss
HTS
a. $b \grave{\varepsilon}+m b \grave{a} \rightarrow b \hat{\varepsilon} m b \grave{a} \rightarrow$ bé $m b \hat{a} \quad$ 'get away from something' leave on (it)

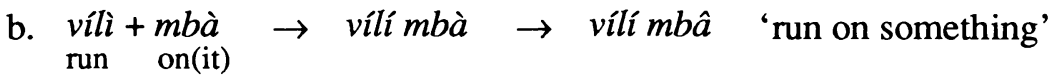

It is not merely a $\mathrm{L}$ that triggers dissimilation; the $\mathrm{L}$ must be in a very specific environment which we describe here. In (24) we provide a partial list of Bandi postpositions with their pronoun clitics. Note that $(24 \mathrm{c}, \mathrm{d}, \mathrm{e}, \mathrm{g}, \mathrm{h})$ all begin with a $\mathrm{L}$, but only the postpositions in (24c) trigger Dissimilation. Verb final L's followed by any of the other pospositional phrases in (24) remain unchanged.
'on'
'to'
'for'
a. $m b a ́$
ngélé
fááwà
'me'
b. i wá
i yélé
i hááwà
'you'
c. mbà
ngèlé
fààwà
'he/she/it/neutral'
d. mù wà
mù yèlé
mù hááwà 8
'us (inclusive)'

\begin{abstract}
7Just as with polarization it is tempting to try to attribute motivation for the dissimilation process to an historical mid tone in the verb final position. Though a mid-tone does not occur in Bandi, a mid tone does occur in Kpelle, a related Southwest Mande language. The Bandi verbs in the examples below all undergo Dissimilation (in the appropriate environments) and their Kpelle cognates all exhibit a mid tone.
\end{abstract}

$\begin{array}{lll}\text { Bandi } & \text { Kpelle } & \\ k \text { uùlà } & k \bar{l} \bar{a} & \text { 'take out' } \\ b \grave{j} & k p \bar{y} \eta & \text { 'to help' } \\ \text { sòu } & s \bar{y} \eta & \text { 'to catch' } \\ \text { sìyè } & s \bar{y} \bar{e} & \text { 'to pick up' }\end{array}$

However, a mid tone analysis remains elusive. Since a mid tone does not occur in surface manifestations of Bandi tone, positing an underlying mid tone with the data available is very abstract. A dissimilation process describes the data satisfactorily enough for this analysis.

${ }^{8}$ For brevity's sake we have omitted from this paper a rule dealing with the replacement of melodies and initial consonant alternation. With one notable exception, when a disyllabic word 

e. nì wà
nì yèlé
nì hááwà
'us (exclusive)'
f. wú wá
w' yélé
wú hááwà
'you (plural)'
g. tì wà
tì yèlé
tì hááwà
'them'
h. wà
yèlé
hààwà
'reflexive'

We interpret the data in (24) in the following way. The underlying forms of the postpositions are mbà, ngèlé, and fààwà respectively. In $(24 \mathrm{~b}, \mathrm{~d}, \mathrm{e}, \mathrm{f}, \mathrm{g})$ it is the final vowel of the clitic pronouns which cause the initial consonant of the postposition to weaken. In $(24 \mathrm{~b}, \mathrm{f})$ the addition of the pronoun clitic with a $\mathrm{H}$ causes $\mathrm{L}$ Tone Displacement to operate placing a $\mathrm{H}$ on the postposition. In $(24 \mathrm{~d}, \mathrm{e}$, g) there is no tone change because the pronoun clitics all have a $\mathrm{L}$.

Having dealt with the obvious cases, we approach (24a). We interpret (24a) as a sequence of a floating $\mathrm{H}$ representing the ' $1 \mathrm{~S}$ ' pronoun (described earlier) followed by the postposition. The sequence of a floating $\mathrm{H}$ followed by the $\mathrm{L}$ on the postposition causes $\mathrm{L}$ Tone Displacement to operate. The result is a $\mathrm{H}$ on the first vowel of the postposition.

The reflexive form in $(24 \mathrm{~h})$ is more difficult to deal with. We speculate that the reflexive morpheme is/was a vowel associated to a $L$. The vowel accounts for the weakening of the initial consonant of the postposition but is apparently lost. The $\mathrm{L}$ has no effect on the tones of the postposition and remains floating. This interpretation is parallel to the ' $2 S$ ' forms in (24b) in which the vowel of the pronoun causes initial consonant weakening but in fast speech the vowel becomes elided.

This leaves (24c). We interpret these forms which are unchanged from the underlying forms as having no clitic pronoun preceding the postposition. Thus, the ' $3 \mathrm{~S}$ ' pronoun is a null morpheme. This is true throughout Bandi. The meaning ' $3 \mathrm{~S}$ ' is unmarked on postpositions, verbs, and inalienable nouns.

As stated above only the postpositions in (24c) provide an environment for dissimilation. These are also the only postpositions that have no preceding pronoun. We claim that the environment for dissimilation is a verb with a final $\mathrm{L}$ followed directly by a postposition with an initial $\mathrm{L}$; that is, there can be no morpheme intervening between the verb and the postposition. This very restricted environment for dissimilation is illustrated in (25). In examples (25a-e) below, the morphemes following the verb all have an initial L. However, the required morphemic environment for dissimilation is not met and Dissimilation does not occur. Only in example (25f) is the required environment supplied and the verb final $\mathrm{L}$ dissimilates to a $\mathrm{H}$. The resulting $\mathrm{H}$ then spreads onto the following postposition (H Tone Spread) resulting in a phrase final falling contour.

with all low melody appears with a weak initial consonant the melody will become HL. The melodies on hááwà 'for' in ( $20 \mathrm{~d}, \mathrm{e}, \mathrm{g})$ are the result of melody replacement. 
(25)

\begin{tabular}{|c|c|c|c|c|}
\hline & $\begin{array}{l}\text { No } \\
\text { change }\end{array}$ & & & \\
\hline a. $b \grave{~}+w a ̀$ & $\rightarrow$ & & bj̀ wà & 'help yourself' \\
\hline b. $\quad b \grave{~}+t \grave{i} w a ̀$ & $\rightarrow$ & & bj̀ tì wà & 'help them' \\
\hline 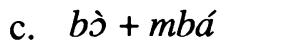 & $\rightarrow$ & & bj̀ mbá & 'help me' \\
\hline d. bj̀ + kéké wá & $\rightarrow$ & & bj̀ kéké wá & 'help a dog' \\
\hline e. bذ̀ + sùwà wà & $\overrightarrow{\text { Diss }}$ & HTS & bj̀ sùwà wà & 'help an animal' \\
\hline 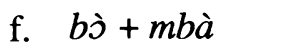 & $\rightarrow \quad b j ́$ mbà & $\rightarrow$ & bó mbâ & 'help it' \\
\hline
\end{tabular}

The dissimilation rule is formulated below.

$\begin{array}{lllll}\text { Dissimilation: } & \mathrm{L} & \mathrm{L} & \mathrm{H} & \mathrm{L} \\ \mathrm{I} & \mathrm{I} & \rightarrow & \mathrm{I} & \mathrm{I} \\ & \mathrm{V}]_{\text {verb }} & \mathrm{CV}]_{\text {postpos. }} & \mathrm{V} & \mathrm{CV}\end{array}$

Dissimilation must be ordered before the polarization rules. Note that in (26) Dissimilation creates a $\mathrm{H}$ which in turn causes the preceding polarizing tone to become a L.

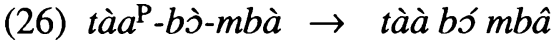

'they can help him'

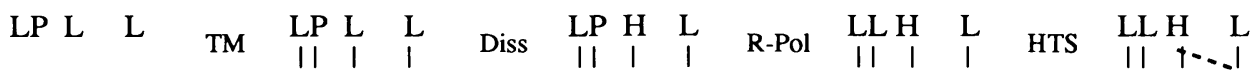
taa bo mba $\rightarrow$ taa bo mba $\rightarrow$ taa bo mba $\rightarrow$ taa bo mba $\rightarrow$ taa bo mba

A possible alternative approach to describing the data presented above is to treat our Dissimilation rule as another type of polarization. Verb final tones affected by this rule might possibly be analyzed as polarizing tones, in addition to those polarizing tones previously discussed. However, such a solution has several drawbacks. First, in the case of dissimilation, L's become H's only in the presence of immediately following postpositions with an inital $\mathrm{L}$ but remain $\mathrm{L}$ in all other cases. If we treat this as another case of polarization, we will be forced to create an ad hoc default rule to turn all remaining P's into L's. Second, the environment for verb tone dissimilation in Bandi is restricted to morphemes that have nothing in common with the morphemes that carry polarizing tone. Thus, we treat dissimilation as a process that is distinct in character from polarization.

\section{Rule Interaction and Opacity in Bandi}

Bandi surface forms are rather remote from their underlying forms. Because of the nature of the rules described above, the presence of underlying L's is often masked. L's may be deleted (by L Tone displacement); they may become part of a 
falling contour (by H Tone Spread); or they may be delinked (by Contour Simplification). In the last case the presence of the $\mathrm{L}$ will only be apparent phonetically when there is a following downstepped $\mathrm{H}$. L's so affected may be either underlying or created by rules such as Dissimilation or Polarization. Furthermore, the actions of Dissimilation and Polarization are obscured when L's in the environments of these rules are altered. Consequently, there is considerable opacity with respect to L's in Bandi.

In (27) we present two derivations to illustrate these complex rule interactions. The underlying tone of the verb stem [ $\left.v v^{u}\right]$ 'to put' is L but in these two derivations the verb receives its surface $\mathrm{H}$ in two different ways. In (27b) the surface $\mathrm{H}$ on the verb stem is the result of Dissimilation. The $\mathrm{H}$ then spreads to the following postposition via the $\mathrm{H}$ Tone Spread rule resulting in a phrase final falling contour. The $\mathrm{L}$ on the postposition that provided the environment for Dissimilation is thus only apparent as part of the falling contour. By contrast, in (30a), the verb stem [ví] surfaces with a H, but in this case the $\mathrm{H}$ is the result of the $\mathrm{H}$ Tone Spread and Contour Simplification rules. This leaves a $\mathrm{H}$ on the verb stem and a floating $\mathrm{L}$ which causes the following $\mathrm{H}$ to be downstepped.

(27) Isolated Forms

[i] ' $1 S$ ' [njè-i] 'water-def'

[mà] 'on (something)'

L $\quad$ L $\quad P \quad L \quad H \quad L$

UR

T-Map

Seg Rules

T-Map

L Tone Displ.

Dissimilation i nje -i pu ma he water-def put $1 \mathrm{~S}$ on

L $\quad$ L $\quad P \quad$ L H L

i nje - i vu ma

$\begin{array}{cccccc}\text { L } & \text { L } & \text { P } & \text { L } & \text { H } & \text { L } \\ \text { I } & \text { I } & \text { I } & \text { I } & \text { I }\end{array}$

i nje - i vu ma

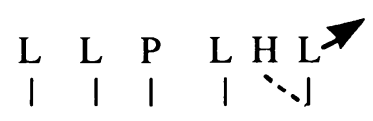

i nje -i vu ma $\begin{array}{llllllllllllllllll}\text { L } & \text { L } & \text { P } & \text { L } & \text { L }\end{array}$

i nje -i pu ma he water-def put (3S) on

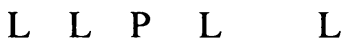

i nje $-\mathrm{i}$ vu ma

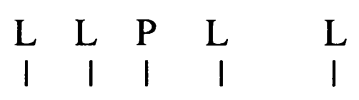

i nje $-i$ vu ma 
Polarization

$$
\begin{array}{ccccc}
\text { L } & \text { L } & \text { H } & \text { L } & \text { H } \\
\text { I } & \text { I } & \text { I } & \text { I } & \text { I }
\end{array}
$$

i nje $-\mathrm{i}$ vu ma

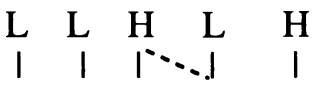

H Tone Spread $\quad$ i nje $\quad-i \quad$ vu ma

$$
\begin{array}{ccccc}
\mathrm{L} & \mathrm{L} & \mathrm{H} & \mathrm{L} & \mathrm{H} \\
\mathrm{I} & \mathrm{I} & N^{\prime} & \mathrm{I}
\end{array}
$$

Contour Simpl. $\quad$ i nje

Downstep

PR

[ì njè-í vú $m ! a ́$ ] 'he put water on me'
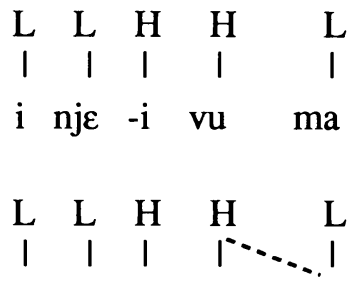

i nje -i vu ma

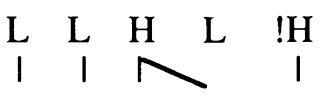

i nje -i vu ma

[ì njècí vú mâ]

'he put water on him/it'

Dissimilation may also occur on the final tone of a disyllabic verb with a HL tone melody. Since the final associated tone of a $\mathrm{HL}$ melody is $\mathrm{L}$, dissimilation to a $\mathrm{H}$ occurs when the verb is followed by a postposition containing the ' $3 \mathrm{~S}$ ' pronoun. The action of Dissimilation is masked by the spread of the verb's final $\mathrm{H}$ onto the postposition. Thus, an underlying string with a H L L melody can surface as $\mathrm{H} \mathrm{H} \mathrm{H}$ due to the combined effect of Dissimilation and the phonetic rules. Just such a process is exemplified in (28) where the verb pélè 'touch me' and the following postposition are in focus.

(28) pélè $\quad m b a ̀$ yí lì $\rightarrow$ pélé mbá y!í lî 'cause me to touch it and go' touch(me) on(it) you go

The data in (28) show nicely the precarious state of L's in Bandi. There are three underlying L's. The first one (pélè) is lost completely due to the fact that Dissimilation turns it into a H. The second L ( $m b a)$ is affected by H Tone Spread, and Contour Simplification and is manifested only as the downstepping of the following $\mathrm{H}$. The third $\mathrm{L}(l i)$ is affected by $\mathrm{H}$ Tone Spread and surfaces as part of the final falling glide. 


\section{The Obligatory Contour Principle and Bandi}

Up to this point in our presentation, the OCP has not been an issue. With the exception of the LLH nouns presented in $\$ 2.4$ we have assumed conformity to the Obligatory Contour Principle (OCP). Thus we have regarded polysyllabic morphemes with all L's or all H's to have a single tone in their underlying forms which is then associated with all tone bearing units in the morpheme by means of Tone Mapping. There are situations in Bandi where adherence to the OCP presents some difficulties. The problem appears when we encounter disyllabic verb stems with a $\mathrm{L}$ tone melody that undergo Dissimilation.

As described above, a $\mathrm{L}$ associated with a final syllable of a CVCV (disyllabic) verb stem will undergo dissimilation to a $\mathrm{H}$ when it is followed by a postposition. Dissimilation presents no problems when it applies to a disyllabic verb stem with a HL melody, but consider what would happen to a simple L melody on a disyllabic verb stem when the $\mathrm{OCP}$ is in force.

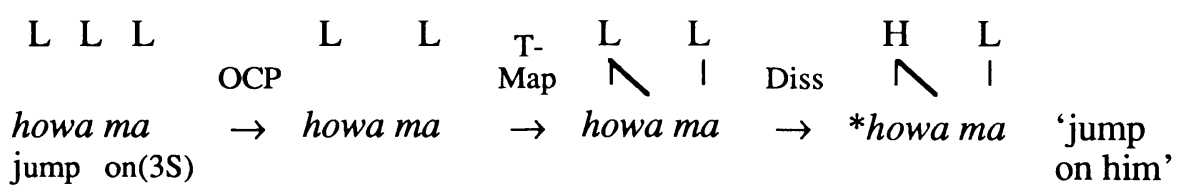

The output of Dissimilation in (29) is incorrect. The correct derivation of 'jump on him' is hòwà $+m a \grave{a} \rightarrow$ hòwá mâ (the final falling tone is due to the H Tone Spread rule). The problem is that only the tone of the final syllable of the verb stem should dissimilate, not the entire melody of the verb. Dissimilation will operate as expected with verb stems of the form CV with a $\mathrm{L}$ melody or CVCV with a HL melody, but a CVCV verb with a L melody, as in (29), results in the incorrect form. One could presumably reformulate the Dissimilation rule so that it would look for a one to many linking of a $\mathrm{L}$, delink it from the last vowel of the verb, insert a $\mathrm{H}$ on the tonal tier, and then associate the $\mathrm{H}$ with the final vowel. However, this cumbersome rule is made necessary only by adherence to the OCP. If we accept the OCP, there is no convenient way to alter the tone on only the final syllable when there is only one tone on the tonal tier that is spread to two or more vowels on the segmental tier. If, however, there were a LL melody on the tonal tier, it would be a simple matter for Dissimilation to change the last tone to $\mathrm{H}$. It is our opinion that any advantages gained by using the OCP are outweighed, in this case, by the heavy cost of rule complexity. 9 We therefore interpret these facts as

\footnotetext{
${ }^{9}$ It should be noted that Leben [1978] was faced with this same type of problem in Mende. Mende has two groups of nouns. One group acts as if it has an LH melody and the other group acts as if it has an LLH melody. In order to account for the different behavior of these two classes of nouns and still maintain the OCP, Leben was forced to devise an extremely complicated set of tone mapping rules.
} 
arguing against the OCP. Furthermore we propose that the correct derivation of 'jump' is as in (30) where the LL melody is maintained.

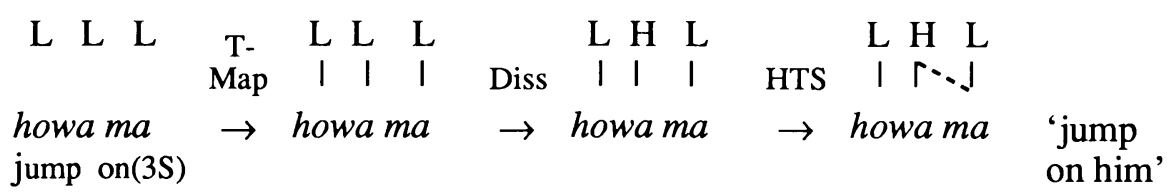

5.1. Is there a LLH Melody? Several linguists have observed an apparent distinction in the related language of Mende between nouns with a LH vs. LLH melody [Dwyer 1971, 1973, 1978; Voorhoeve 1975; Leben 1971; Spears 1967]. Leben [1978] specifically rejected this distinction assuming that the OCP would not allow a LLH melody. Consequently he represented nouns of these classes as both underlyingly $\mathrm{LH}$ and invoked an extremely complex set of tone mapping rules (see Sindlinger [1981] for a criticism of this treatment). A similar distinction exists in Bandi nouns though not always on cognates of the Mende nouns. The existence of underlying LLH melodies will, of course, argue against the OCP.

5.1.1. Bandi LH and LLH melodies. Above we presented a three syllable LLH melody noun, ndذw ذ̀ló 'earth'. The simplest explanation for such a word is that this noun has a LLH melody which maps tones to segments in a one to one manner. We present here evidence that certain two syllable nouns with an apparent LH melody have in fact underlying LLH melodies.

In isolation the Bandi nouns pèlé 'house' and nyàhá 'woman' both have a LH tone pattern. However, as may be seen in (31), these nouns affect some following morphemes differently. Notice the postposition 'on' in (31c) exhibits a H following 'house' but a falling tone following 'woman'. Futhermore, the verb 'to push' in (31d) has a HH pattern following 'house' but a $\mathrm{H}$ !H pattern following 'woman'. It should be noted that the two nouns in (31) are each representative of two large classes of frequently occuring nouns.
a. isolation
pèlé
nyàhá
b. definite
$p \grave{\varepsilon} l \hat{\varepsilon}-\hat{\imath}$
nyàhá-î̀
c. postposition phrase
pèlé wá
nyàhá wâ
d. verb phrase
pèlê lévé
nyàhá lév!é

The L Tone Displacement (LTD) rule described above helps us to account for pèlé wá in (31c) and pèlé lévé in (31d). We assume that the underlying melody for 'house' is LH and the melody for the postposition 'on' and the verb 'to cut' is L 
and $\mathrm{LH}$ respectively. These forms may then be derived as in (32) through the action of only one rule, namely LTD.
(32) L H L
Seg
Rules
$\begin{array}{cccc}\text { T- } & \text { L } & \text { H } & \text { L } \\ \text { Map } & \text { I } & \text { I }\end{array}$
$\begin{array}{lll}\mathrm{L} & \mathrm{H} & \mathrm{E} \\ \mathrm{L} & \mathrm{I}\end{array}$
a. pele mba $\rightarrow$ pelewa
$\rightarrow \quad$ pele wa
LTD
pele wa
$\rightarrow$ pelewa pèléwá

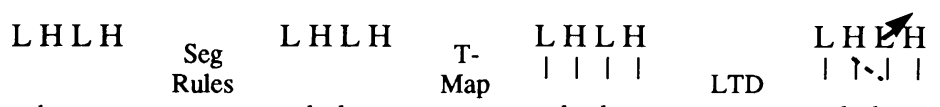
b. pele teve $\rightarrow$ peleleve $\rightarrow$ pele leve $\rightarrow$ peleleve pèlélévé

While LTD accounts for the pèlé examples, it will not explain the nyàhá examples. In fact all nouns of the nyàhá class appear to be exceptional to $\mathrm{L}$ Tone Displacement. Thus, part of the class distinction between these two types of nouns is in their different behavior with respect to the LTD rule.

Earlier we pointed out that ndذws̀ls' 'earth' is also exceptional to LTD. For example, the postposition $w \grave{a}$ 'on' exhibits a falling contour following the LLH noun for 'earth' in ndذ̀w ̀̀ló wâ just as it did following nyàhá in (31c). Without the constraint of the OCP the melody for 'earth' appears to be a simple LLH melody.

We propose that the commonality shared by ndj̀ẁló and nyàhá is that both have an underlying LLH melody. While the association of the LLH melody to ndذ̀ẁls is a straightforward one-to-one mapping, association of this melody to nyàhá involves another complication. In the derivation of nyàhá and nyàhá wâ, Tone Mapping will create a LH contour on the end of the noun, but rising contours never appear on the surface in Bandi. They are, however, realized phonetically as a slightly higher H.10 In (31) we demonstrated the differences in morphological behavior between pèlé class and nyàhá class nouns. In addition, when the isolation forms of these two classes are compared, the high pitch of the nyàhá class all manifest a slightly higher pitch than those of the pèlé class. We assume that a late phonetic adjustment rule converts a rising pitch to a slightly raised $\mathrm{H}$. Consequently in our derivations we will leave LH sequences mapped to a single vowel rather than try to make a distinction between two different H's.

By assuming an underlying LLH melody we can now derive the forms in (33) without reference to LTD.

a.

$$
\text { L LH L }
$$

UR nyaha wa

woman on b.

L L H L

ndowolo wa

earth on

${ }^{10}$ For a fuller treatment of this phenomenon see Rodewald [1989]. 


\begin{tabular}{|c|c|c|}
\hline & $\begin{array}{c}\text { L LH L } \\
\text { I } \mathrm{V} ~\end{array}$ & $\begin{array}{cccc}\mathrm{L} & \mathrm{L} & \mathrm{H} & \mathrm{L} \\
\mathrm{I} & \mathrm{I} & \mathrm{I} & \mathrm{I}\end{array}$ \\
\hline \multirow[t]{2}{*}{ T-Map } & nyaha wa & ndowolo wa \\
\hline & 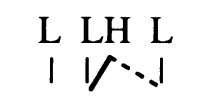 & 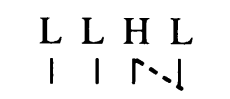 \\
\hline \multirow[t]{3}{*}{ HTS } & nyaha wa & ndowslo wa \\
\hline & c. & $\mathrm{d}$. \\
\hline & $\mathrm{L} \mathrm{LH} \mathrm{LH}$ & $\mathrm{L} \mathrm{L} \mathrm{H} \mathrm{L} \mathrm{H}$ \\
\hline \multirow[t]{2}{*}{ UR } & $\begin{array}{l}\text { nyaha leve } \\
\text { woman cut }\end{array}$ & $\begin{array}{l}\text { ndowols leve } \\
\text { earth cut }\end{array}$ \\
\hline & $\begin{array}{l}\mathrm{L} \text { LH L H } \\
|\mathrm{V}| \mathrm{I}\end{array}$ & 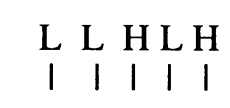 \\
\hline \multirow[t]{2}{*}{ T-Map } & nyaha leve & ndowolo leve \\
\hline & $\begin{array}{l}\text { L LH L H } \\
|V \cdot|||\end{array}$ & $\begin{array}{l}\mathrm{L} \\
||_{\mid}\end{array}$ \\
\hline \multirow[t]{2}{*}{ HTS } & nyaha leve & ndowslo leve \\
\hline & $\begin{array}{l}\text { L LHLH } \\
\mid \text { V.于 I }\end{array}$ & $\underset{\mid}{L} \underset{\mid}{L} \underset{N}{H} \mathrm{~L}_{1}$ \\
\hline \multirow[t]{2}{*}{ Contour Simp } & nyaha leve & ndowolo leve \\
\hline & $\overbrace{\text { L LH L!H }}^{\text {L }}$ & $\underset{\mid}{\mathrm{L}} \underset{\mid}{\mathrm{L}} \mathrm{N}_{\text {I }}^{\mathrm{L} ! \mathrm{H}}$ \\
\hline Downstep & nyaha leve & ndowolo leve \\
\hline
\end{tabular}

We claim that the nouns in (33) all have underlying LLH melodies. We view these forms as not exceptional to LTD, rather LLH nouns are excluded because the condition on LTD states that $\mathrm{H}$ is part of a LH or H melody.

5.1.2. Nominal compounds. As additional evidence for the LLH distinction we present data from nominal compounds where nyàhá and pèlé class nouns differ in their behavior. In the simplest cases compounding is merely the joining of two 
morphemes and tone mapping is a simple one to one mapping of the underlying tones of both. ${ }^{11}$ This simple one to one mapping is demonstrated in (34).

(34) nìkà + tèvé-ndáâ $\rightarrow$ nikà-lèvé-ndáâ

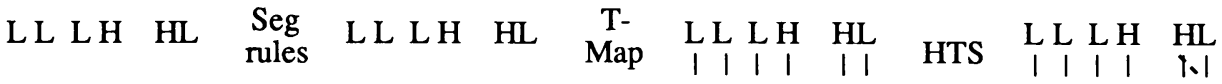
nika-teve-ndaa $\rightarrow$ nika-leve-ndaa $\rightarrow$ nika-leve-ndaa $\rightarrow$ nika-leve-ndaa

However compounds containing disyllabic LLH and LH nouns can not be treated as simply. Compare the tone of the verb tevelleve in (35) with (34). Furthermore, the tone of 'woman' becomes LL in (35b).
a. pèlé-lévé-ndáâ
'the act of cutting a house'
b. nyàhà-lévé-ndáâ
'the act of cutting a woman'

We can derive (35a) with existing rules. We demonstrate this in (36).

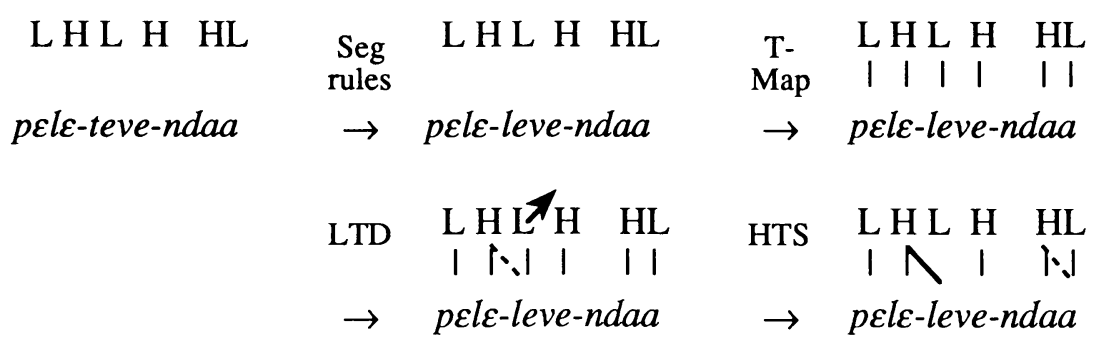

In (36) the underlying tones are mapped in a one to one manner and LTD accounts for the missing $\mathrm{L}$ on tèvé. However, (35b) presents a complication. It appears that the LLH melody is spread over two morphemes; the LL appearing on 'woman' and the $\mathrm{H}$ appearing on 'cut'. We propose a word formation rule which deletes the first tone of the second morpheme in those cases when the first morpheme has more tones than vowels. Tones are then mapped normally.
a. nyàhá + lèvé-ndáâ $\rightarrow$
nyàhà-lévé-ndáâ
'the act of cutting a woman' woman cut-nom. suf.
b. nyàhá + lò-ndáâ $\rightarrow$ woman see-nom. suf. morpheme's tone melody. This melody can differ depending upon the class of nouns and morphemes involved. 
Sample derivation

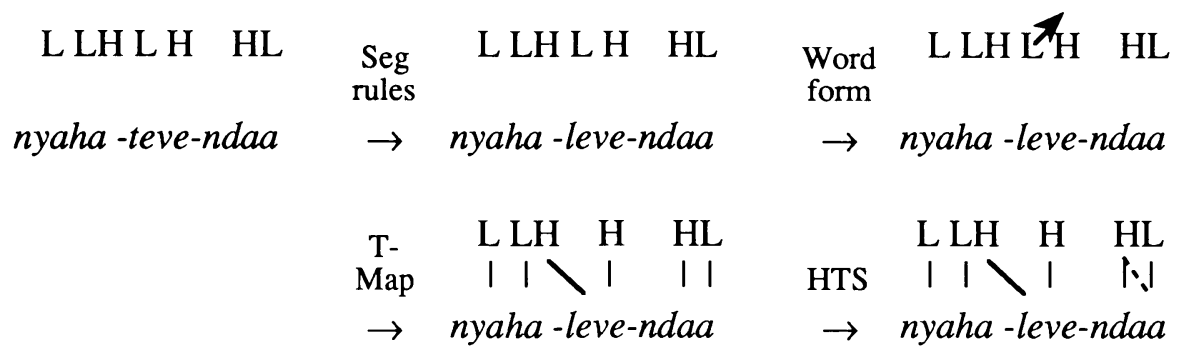

When a LLH melody occurs on a three syllable morpheme our word formation rule does not apply because of the restriction in the rule which allows it to apply only when there are more tones than vowels. Thus, in (38) tone mapping procedes normally.

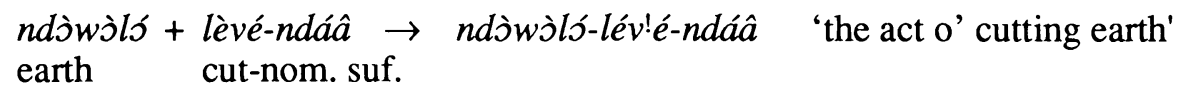

$\begin{array}{ccccccc}\text { L LH LH } & \text { HL } & \text { Seg } & \text { L LH LH } & \text { HL } & \text { Word } \\ & \text { rules } & & \text { form }\end{array}$

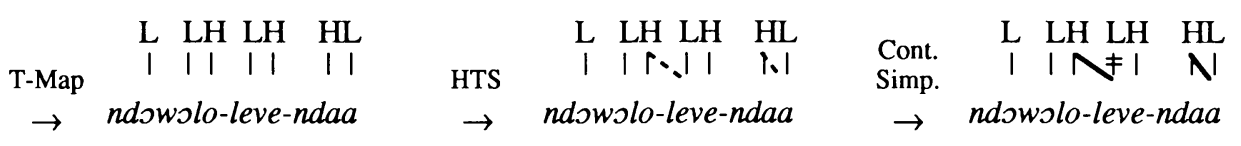

$\begin{array}{llll}\text { Down- } & \mathrm{L} & \mathrm{LHL} ! \mathrm{H} & \mathrm{HL} \\ \text { step } & \mathrm{I} & \mathrm{N} & \mathrm{N} \\ \text { ndowolo-leve-ndaa } & \end{array}$

Disyllablic nouns which react identically to nyàhá are quite numerous. We provide here a partial list of these nouns which we claim have an underlying LLH melody.

$\begin{array}{clll}\text { (39) nyàhá } & \text { 'woman' } & \text { ndòpó } & \text { 'child' } \\ \text { sìyé } & \text { 'man' } & \text { jàkó } & \text { 'monkey' } \\ \text { fàsá } & \text { 'shrimp' } & \text { ngàlá } & \text { 'god' }\end{array}$

5.2 Summary of OCP arguments. We have presented two major arguments against the OCP. First, we argued that the Dissimilation rule becomes unduly complicated if the OCP is invoked. Second, we established the need for underlying 
LLH melodies to explain forms like ndう̀wう̀ló 'earth' as well as the difference between the nyàhá and pèlé classes of nouns.

\section{Conclusion}

This paper has described and formalized several of the major tone rules of Bandi. Some additional rules exist that have been described in Rodewald [1989], but we have chosen to limit the scope of the present paper. The tone rules of Bandi were described as participating in two classes, phonetic rules that operate in the domain of the phrase, and morphological rules that have limited morphemic environments. It was proposed that for Bandi polarizing tones must be treated as an underspecified tonal autosegment present underlyingly on the tonal tier. This tone is then associated to tone bearing units via Tone Mapping. The actual phonetic pitch height of the polarizing tone is supplied by a combination of morphological and phonetic rules. This treatment proved necessary in order to prevent inappropriate spreading of tones either by rule or Tone Mapping. Thus, polarizing tone has a status equivalent to that of an underlying $\mathrm{L}$ or $\mathrm{H}$.

Adherence to the OCP causes unnecessary rule complication in Bandi. Single tone word melodies created by the OCP on disyllabic stems are incorrectly affected by the Bandi morphological rules of Dissimilation and L Tone Displacement. It is possible to maintain the OCP by making rules sensitive to features such as a one to many linking of tones to segments and requiring the rule to insert and associate tones. We maintain that simpler rule formation is obtained if we suspend the OCP and allow melodies with a sequence of like tones in Bandi.

We presented data showing that Bandi nouns with a $\mathrm{LH}$ pattern fall into two distinct classes according to their behavior. We argued that the best course is to posit underlying LLH melodies for some disyllabic nouns. Again, the action of the OCP would cause much rule complication or force us to a much more elaborate system of tone mapping much as Leben [1978] was forced to do in Mende. Finally, the opacity of underlying $\mathrm{L}$ tones was discussed. 


\section{REFERENCES}

Bird, Charles. 1971. "Observations on initial consonant change in Southwestern Mande." In C.W. Kim and H. Stahlke (eds.), Papers in African Linguistics, pp. 153-174. Edmonton, Alberta: Linguistic Research Incorporated.

Conteh, Patrick, Elizabeth Cowper, Deborah James, Keren Rice \& Michael Szamosi. 1983. "A reanalysis of tone in Mende." In Jonathan Kaye \& Hilda Koopman (eds.), Current Approaches to African Linguistics, Vol.2, pp. 127137. Dordrecht, Holland: Foris Publishers.

Dwyer, David. 1973. "The comparative tonology of Southwestern Mande nominals." PhD dissertation, Michigan State University.

Dwyer, David. 1974. "The historical development of Southwestern Mande consonants." Studies in African Linguistics 5:59-94.

Goldsmith, John. 1976. Autosegmental Phonology. Bloomington: Indiana University Linguistics Club.

Hyman, L.M. \& R.G. Schuh. 1974. "Universals of tone rules: evidence from West Africa." Linguistic Inquiry 5:81-115.

Leben, William R.. 1978. "The representation of tone." In Victoria Fromkin (ed.), Tone: A Linguistic Survey, pp. 177-219. New York: Academic Press.

Rodewald, Michael. 1989. "A grammar of Bandi and Mende tone." M.A. Thesis, University of Texas at Arlington.

Schuh, Russell G. 1978. "Tone rules." In Victoria Fromkin (ed.), Tone: A Linguistic Survey, pp. 221-56. New York: Academic Press.

Sindlinger, Dan \& Richard Thompson. 1975. "A survey of the Gbande language.” Unpublished $\mathrm{ms}$.

Welmers, William. 1958. "The Mande languages." Georgetown University Monograph Series in Languages and Linguistics 11, pp. 9-24. Washington, D.C.: Georgetown University Press. 